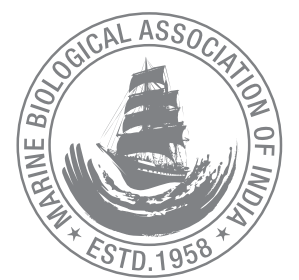

\title{
Allometric relationships of short neck clam Paphia malabarica from Dharmadom estuary, Kerala
}

\author{
Sujitha Thomas \\ Research Centre of Central Marine Fisheries Research Institute, P.B. No 244, Hoige Bazar \\ Mangalore, Karnataka, India - 575001. \\ *Correspondence e-mail: sujithacmfri@yahoo.co.in
}

Received: 07 Feb 2013, Accepted: 20 May 2013, Published: 30 May 2013

Original Article

\begin{abstract}
Length weight relationship and other allometric relationships were studied for shortneck clam Paphia malabarica. Lengthweight and total weight-flesh weight relationship in males and females were significantly different $(p<0.01)$. The rate of growth in all other relationship studied were not significantly different between sexes. In length- weight relationship it showed isometric growth and in length-width and length-depth it showed negative allometric growth. The determination coefficient $\left(r^{2}\right)$ was higher in length-depth than in length-width relationship indicating that the shell growth in depth is less variable than shell growth in width and negative allometry indicates that width and depth increase are inferior to length increase.
\end{abstract}

Keywords: Paphia malabarica, length weight relationship, isometric growth, negative allometry.

\section{Introduction}

The study of length- weight relationship and dimensional relationships assumes great importance in fishery biology research, as it provides a mathematical relationship between them, enabling the derivations of one variable from other. Often growth is estimated by measuring shell dimensions or the volume of the animal (Hibbert, 1977; Bailey and Green,
1988) because they are simple, non- destructive methods that can be easily completed in the field. Once the allometric relationship is established, shell measurement is a sufficient surrogate to estimate biomass and total flesh production (Hibbert, 1977; Rodhouse et al., 1984). Studying bivalve growth and establishing allometric relationships are essential for generating useful information for managing resources and understanding changing environmental conditions and pollution (Palmer, 1990). Information on allometry helps to understand the ideal conditions under which bivalves show proportionate growth and also to determine the size at which harvest can be intensified so as to maximize production.

In India, allometric relationships of several bivalves have been studied. The important studies are those of Durve and Dharmaraj (1965, 1970), Alagarswami (1966), Parulekar et al., (1973), Alagaraswami and Chellam (1977), Mohan and Damodaran (1981), Mohan et al. (1984) and Rao (1988). Studies on Paphia malabarica are limited to the length- weight relationship by Rao (1988) from Mulky Estuary in Dakishna Kannada, and dimensional variations by Appukuttan (1993) from Ashtamudi Estuary in south Kerala. The present study gives details of the different allometric relationships viz., length-weight, length-width, length-depth, total weight-flesh weight of male and female Paphia malabarica. The regression 
equations were calculated separately for male and female and the relationships were statistically compared between sexes.

\section{Material and methods}

Length-weight, length-depth, length-width , total weight -shell weight and total weight - flesh weight relationships were done separately for 383 male and 323 female clams of size ranging from 22-52 mm, collected from the Dharmadom estuary. The clams were weighed in an electronic balance with a sensitivity of $0.1 \mathrm{~g}$.The length, width and depth were recorded using digital calipers with $0.01 \mathrm{~mm}$ accuracy. Maximum antero-posterior length was taken as total length (APL), maximum length in the dorso-ventral axis (DVL) from umbo as width (height) and maximum thickness of clam when both valves closed as depth. The shells were opened, sex differentiated, and the meat carefully removed. Wet meat weight was taken after draining and blotting the meat off excess water content. Air dried shells were weighed to 0.1 $\mathrm{g}$ accuracy. Analysis was carried out separately on them as followed by Appukuttan (1993).

Analysis of covariance (Snedecor and Cochran, 1967) technique was used to test for significant difference in relationship between sexes at $5 \%$ level. For length-weight, regression analysis was performed using Data Analysis package in EXCEL software. The correlation coefficient ( $r$ ) was determined to know the strength and pattern of association between the two variables. Other allometric relationships between body parameters were expressed as $Y=a+b X$, were $a$ and $b$ are constants, $Y$ is the body parameter and $X=$ length or weight. Student'st test was carried out with a confidence level of \pm $95 \%$ expressed by the following equation (Sokal and Rohlf, 1987)

$$
t_{s}=(b-3) / S_{b}
$$

Where $t_{s}=$ test value, $b=$ slope, $S_{b}=$ standard error of the slope (b)

For length-width and length-depth relationship, analysis of covariance was done using a test with a confidence level of $\pm 95 \%(p=0.05)$ was applied, expressed by the following equation (Sokal and Rohlf, 1987)

$$
t_{s}=(b-1) / S_{b}
$$

Where $t_{s}=t$-test value; $b=$ slope (relative growth rates of variables); $S_{b}=$ standard error of the slope (b).

Subsequently, the comparison between the obtained value of the $t$-test and tabled critical value of the $t$-test, allowed the determination of the statistical significance of the $b$ value and its inclusion in the isometric or allometric ranges $(b=3$ or $b$ $=1$ for isometric or $b<3$ or $b<1$ for negative allometry or $b>3$ or $b>1$ for positive allometry).

\section{Results}

\section{Total length - total weight relationship}

The regression equations for the length-weight relationship of males $(n=323)$, females $(n=384)$ and pooled $(n=707)$ were calculated as:

Males : $\log W=-1.0679+2.8977 \log L(r=0.9605)$

Females : $\log W=-1.3582+3.1067 \log L(r=0.9632)$

Pooled : $\log W=-1.0869+2.9844 \log L(r=0.9614)$

Where $W$ is the total weight $(\mathrm{g})$ and $L$ the total length $(\mathrm{cm})$. The calculated curves of total length-total weight relationship for males and females are shown in Fig 1. A and B.

The length-weight relationship for males, females and sexes pooled in the form $W=a L^{b}$ is as follows:

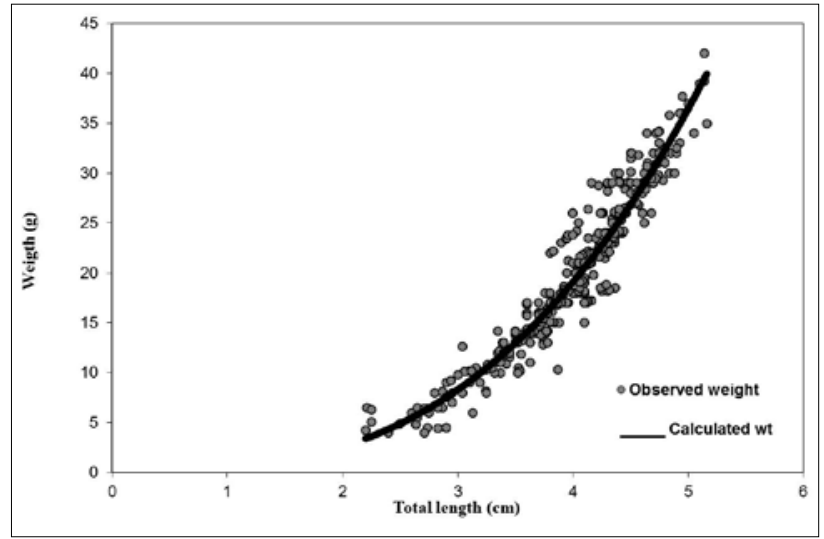

Fig.1A Relationship between total length and weight of male P. malabarica.

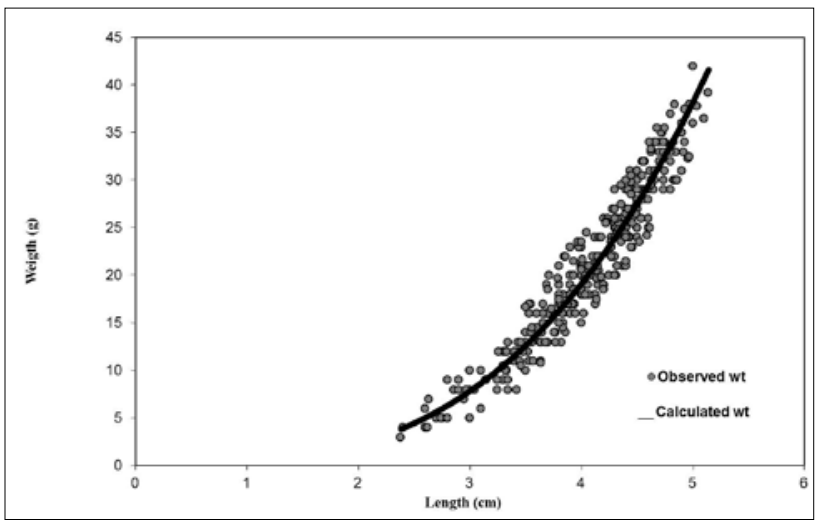

Fig.1B Relationship between total length and weight of female P. malabarica. 
Males : $W=0.343736 \mathrm{~L} 2.89774$

Females : $W=0.257121 \mathrm{~L}^{3.106693}$

Pooled : $W=0.337274$ L 2.98443

The $t$ test was conducted to test the isometry and the values of $t$ calculated were 0.8357 for females, 0.7615 for males and 0.1179 for pooled samples. The values did not show significant difference at $95 \%$ confidence level indicating isometric growth.

\section{Length - depth (height) relationship}

The regression equation for length - depth relationship is as follows:

$$
Y=0.69839 X+0.19399(r=0.935600)
$$

Where $Y$ is the total depth and $X$ the total length $(\mathrm{cm})$. The regression equation between male and female were tested for equality through analysis of covariance (ANACOVA). As the slope does not differ significantly for both sexes, $t$ test was conducted for pooled samples to test the isometry. The value of $t$ calculated for pooled samples was 2.0949 which showed significant difference at $95 \%$ confidence level and the $b$ value for the same, indicated negative allometric growth.

\section{Length-width relationship}

The regression equation for length-width relationship is as follows:

$$
Y=0.54505 X-0.05780(r=0.874880)
$$

where $Y$ is the total width and $X$ the total length $(\mathrm{cm})$.

The regression equation between male and female were tested for equality through analysis of covariance (ANACOVA). The values of slope do not differ significantly at $1 \%$ level

As the slope does not differ significantly for both sexes, $t$ test was conducted for pooled samples to test the isometry. The value of $t$ calculated for pooled samples was 2.6957 which showed significant difference at $95 \%$ confidence level and the $\mathrm{b}$ value for the same indicated negative allometric growth.

\section{Total weight -flesh weight relationship}

The regression equation for the flesh weight-total weight relationship of males $(n=323)$, females $(n=384)$ and pooled $(n=707)$ were calculated. The pooled equation is

Pooled: $Y=0.11535 X+0.14346(r=0.731258)$ where $Y$ is the flesh weight $(\mathrm{g})$ and $X$ is the total weight $(\mathrm{g})$. The calculated curves of total weight-flesh weight relationship for males and females are shown in Figure 2. A and B

The regression equation between male and female were tested for equality through analysis of covariance (ANACOVA). The values of slope differ significantly at $1 \%$ level.

\section{Total weight-shell weight relationship}

There was no significant difference between $b$ values of male and female, the regression equation for total weight to shell weight therefore are pooled and calculated as:

Pooled: $Y=0.73878 X+0.16246 \quad(r=0.975535)$

where $Y$ is the shell weight $(\mathrm{g})$ and $X$ is the total weight $(\mathrm{g})$. The regression equation between male and female was tested for equality through ANACOVA. The values of slope do not differ significantly at $1 \%$ level.

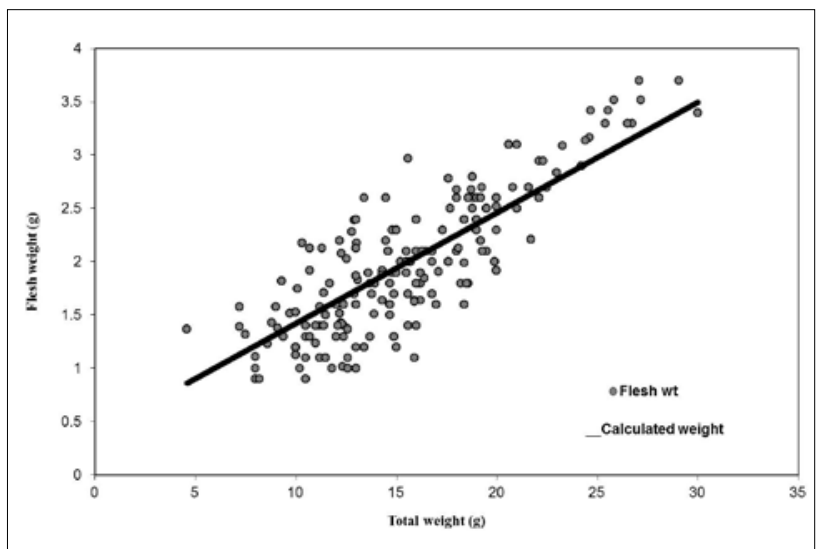

Fig.2 A Relationship of total weight to flesh weight of male P. malabarica

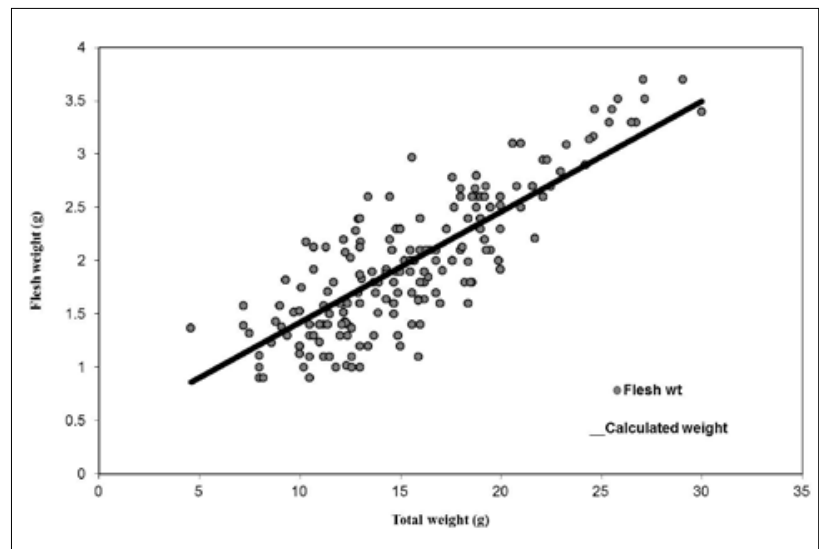

Fig.2 B Relationship of total weight to flesh weight of female P. malabarica 
From the results it is observed that length-weight and total weight -flesh weight relationship in males and females were significantly different $(p<.01)$ and the rate of growth in all other relationship studied were not significantly different between sexes. In length- weight relationship it showed isometric growth and in length-width and length-height it showed negative allometric growth.

\section{Discussion}

In allometric relationship involving length and weight the $b$ value lies between 2.5 and 4.5 (Shafee, 1978). The dimensional variaitons observed clams and mussels by different workers showed that variation in the body proportion exists and some workers have attributed it to environmental conditions and nature of substratum (Durve and Dharmaraj, 1965, 1970; Ansari et al., 1979;, Alagarswami and Chellam, 1977; Mohan and Damodaran, 1981). Rao (1988) estimated the lengthweight relationship of $P$. malabarica from Mulky estuary as $\mathrm{W}$ $=0.000122443 \mathrm{~L}^{3.2640}$ and Appukuttan (1993) observed the length weight relationship of same species from Ashtamudi Estuary as $W=0.1172 L^{3.5176}$ and $W=0.1975 L^{3.0682}$ in two stations in the estuary. He also observed that $P$. malabarica from Ashtamudi showed variations in dimensional relationships except length-width for clams from two stations. Although, the precise cause for heterogeneity of shell characters and changes in meat weight proportion from the two stations are not clear, one reason could be the difference in environmental conditions prevailing in two stations.

The length-weight relationship in male and female $P$. malabarica has not been studied from Indian waters and this is the first study of its kind. In the present study, it is seen that the $b$ value for male and female lies between 2.989 and 3.107 within the reported range of 2.5 to 4.5 (Shafee, 1978). It is seen that the $b$ value of female is higher than that of the male, indicating that at a given length, female is slightly heavier than the male.

In the present study significant difference was observed between the length-weight relationship and total weight to flesh weight relationship of male and females of $P$. malabarica collected from Dharmadom estuary. Although precise cause for this heterogeneity in male and female clams is not clear, it can be attributed to the difference in weight gain during the reproductive cycles as reported by Murawski (1982) and Fritz (1991). Park and Oh (2002) when, studying the length-weight relationship of 12 species of bivalves observed that of this, eight species showed isometric growth at $95 \%$ confidence limit of b. Gaspar et al., (2001) studied six species of clams of Veneridae family and found that two species showed isometric growth. The present study has revealed that in $P$. malabarica the length-weight relationship showed isometric growth rate. Gaspar et al. (2002), when studying the shell morphometrics of the common bivalve species of Algarve coast, found that, of the six species of family Veneridae, Venus fasciata showed negative allometry in length-width relationship and lengthdepth relationship and Chamelea gallina showed negative allometry in shell width-shell length relationship. P. malabarica, which belongs to family Veneridae, exhibited similar allometric growth pattern. The determination coefficient $\left(r^{2}\right)$ was higher in length-depth than in length-width relationship indicating that the shell growth in depth is less variable than shell growth in width and negative allometry indicates that width and depth increase are inferior to length increase. Gaspar et al. (2002) found similar negative allometric growth in Donax trunculus and Acanthocardia paucicostata and have attributed it to the substrate which it inhabits and the burrowing nature of the bivalve. Since $P$. malabarica is found near the bar mouth of the estuary, these negative allometry may be an adaptive strategy to improve burrowing efficiency and depth within the substrate, avoiding dislodgement from the bottom sediments by local hydrodynamics. Although the species morphometric relationships may vary due to hydrological and sedimentological features in different geographic regions the information on different allometric relationships forms an important input for proposing management measure for bivalve fishery.

\section{References}

Alagarswami, K. 1966. Studies on some aspects of biology of the wedge-clam Donaxfaba Gmelin from Mandapam coast in the Gulf of Mannar. J. Mar. Biol. Ass. India., 8(1): 56-75.

Alagarswami, K. and Chellam. 1977.Changes of form and dimensional relationship in the pearl oyster Pinctadafucata from Gulf of Mannar. Indian J. Fish., 24 (1\&2): $1-14$.

Ansari, Z.A., S.A. Nair, S.N. Harkantra and A.H. Parulekar. 1979. Studies on dimensional relationships in green mussel Mytilus (=Perna) viridis from three environments. Mahasagar, 11: 201-205.

Appukuttan, K.K. 1993. Studies on the ecobiology and fishery of Paphia malabarica Chemnitz (Veneridae: Bivalvia) from Ashtamudi estuary, southwest coast of India. Ph.D thesis, University of Kerala.185 pp. (Unpublished).

Bailey, R.C. and R.H. Green. 1988. Within-basin variation in the shell morphology and growth rate of fresh water mussel. Can. J. Zool., 66: 1704-1708.

Durve, V.S. and S.J. Dharmaraja. 1965. Study on the dimensional relationship in the clam Meretrix casta (Chemnitz) collected from two localities. J. Mar. Biol. Ass. India, 7(1) 69-79.

Durve, V.S. and S.J. Dharmaraja. 1970.0n the probable change of form in the clam Meretirix casta (Chemnitz) during its growth. Proc. Sym. Mollusca Cochin., Mar Biol. Ass. India, Part 2: 387-395.

Fritz, L.W. 1991. Seasonal condition change, morphometrics growth and sex ratio of the ocean quahog, Arctica islandica (Linnaeus, 1767) of the New Jersey, U.S.A.J. Shellfish Res., 10: 79-88.

Gaspar, B. Miguel, N. Miguel Santos, Paulo Vasconcelos and Carlos C. Monteiro. 2002. Shell morphometric relationship of the most common bivalve species (Mollusca: Bivalvia) of the Algarve coast (southern Portugal). Hydrobiologia, 477: 73-80.

Gaspar, M.B., M.N. Santos and P. Vasconcelos, 2001. Weight- length relationship of 25 bivalve species (Mollusca: Bivalvia) from the Algarve coast (southern Portugal). J. Mar. Biol. Ass. U.K., 81: 805-807.

Hibbert, C. J. 1977. Growth and survivorship in a tidal-flat population of the bivalve Mercenaria mercenaria from Southampton Waters. Mar. Biol., 44:71-76.

Mohan . M. V., R. Damodaran and K.Y.M. Salih. 1984. Allometric studies in the clams Meretrix casta Chemnitz. Mahasagar, Bull. Natn. Inst. Oceanogr.,17: 119-123.

Mohan, M.V and R.Damodaran. 1981. Allometric relationship in the clam Sunetta scripta L. Indian J. Mar. Sci., 10: 198-200. 
Sujitha Thomas

Murawski, S.A., J.W. Ropes and F.M. Serchuk. 1982. Growth of the ocean quahogs Arctica is landica, in the middle Atlantic. Fish Bull., 80: 21-34.

Palmer, A.R.1990. Effect of crab effluent and scent of damaged conspecifics on feeding, growth, and shell morphology of the Atlantic dogwhelk Nucella lapillus (L). Hydrobiologia, 193:155-182.

Park.K.Y. and C.W. Oh. 2002. Length weight relationship of bivalves from Coastal waters of Korea. Fishbyte section. Naga, ICLARM Q. 25(1): 21-22.

Parulekar, A.H. S. N. Dwivedi and A.K. Dhargealkar. 1973. Ecology of clam beds in Mandovi Cumderjia canal and Zuari estuary system of Goa. Indian J. Mar. Sci., 2: 122-126.

Rao, G.S. 1988. Biology of Meretrix casta (Chemnitz) and Paphia malabarica (Chemnitz) from Mulky estuary, Dakshina Karnataka. In National seminar on shell fish resources and farming - Tuticorin. 19-21 January 1987. Bull. Cent. Mar. Fish. Res. Inst., 42(1): 148-153.
Rodhouse, P. G., C.M. Roden, G.M. Burnell, M.P. Hensey, T. Mcmahon, B. Ottway and T.H. Ryan. 1984. Food source, gametogenesis and growth of Mytilus edulis on the shore and in suspended culture: Killary Harbour, Ireland. J. Mar. Biol. Ass. U.K., 64: 513-529.

Shafee, M.S. 1978. Studies on various allometric relationships in intertidal green mussel Perna viridis Linnaeus of Ennore estuary, Madras. Indian J. Fish., 23 (1\&2): $1-9$.

Snedecor, G.W. and W.G. Cochran. 1967. Statistical Methods.Oxford and IBH publishing Co., New Delhi, Sixth edition, 539 pp.

Sokal, R.R and F.J. Rohlf. 1987. Introduction to biostatistics, $2^{\text {nd }}$ Ed. New York. W.H. Freeman and company. 